\title{
日本の都市の中心商店街とその店舖
}

\author{
杉 村 暢 二*
}

まえがき

都市の中心商店街とその店舗について，実地調查の結果を御報告し，御批判を乞う次第である。

ある程度の人口をもち，そこに都市的な機能がそなわつてくると，盛り場（ここては中心商店街と呼ぶ） が発生してくるものであり，盛り埸は，都市の成立にとつて必須なるのである。

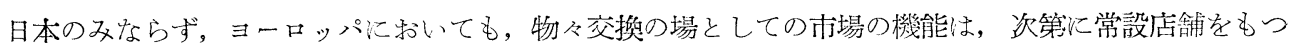
通りへ変化していつた ${ }^{1 ”} 。$ 常設店舗をもつ通りは，商店街と呼ばれ，都市には，一つならず,いくつか成立 している場合が多い2!。その中でも，もつとも中心的な颜店街は，その位置する都市の性格を反映する顔に たとえられるものであり，中心就店街の繁栄の程度，および，その性格は都市の Symbol といつても過言 ではないであるう。このように，都市にとつて，重要な意義をもつ中心商店街について，その店舗との関 係注いて以下述べてみたい。

\section{I. 中心商店街と構成店舗}

1. 都市地域と商店街の店赤

商店街とは，一般にバライティーに䈏んだ，乙かも覧迴り品を主とした店舗から構成され，ある種の共 同組織をもつた通りである。

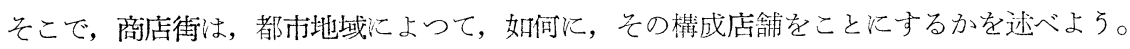

まず，小都市の商店街として，伊豆半島の中心町下田町について商店街としての組織をもつ下出銀座， 伊攀町銀座，東部商店会の 3 つの店舗構成を示すと第 1 表の上 5 亿なる。

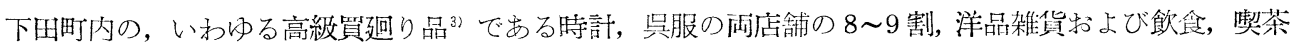

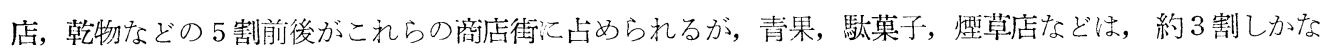
いことがわかる。一方，3商店街の中でも，下田，伊樊町の两銀座が，東部商店会より高紣筫㢠り品の構 成の割合が高いことが指摘されよう。

同じく，都市嫢模の大なる中都市盛同化ついて，都市地域と商店街との関係をみると ，およそ20を算 光る謪店街の中，時計などの文化品は，都市の中心地区から中間周辺地区に间つて，21.3\%，12.8\%， $7.0 \%$ 減じていることが看取れ，飲食料品については反対の関係が指摘される。

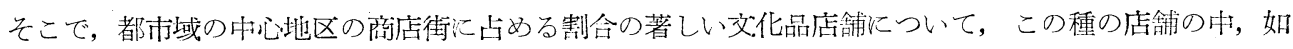
何なる商品を販売する店舗が，もつとも集中しているかを，大都市広島市について，さらに検討しょう5。

第 2 表は, 広島市域炕拈る备地区毎の文化品店舗に相当する 9 種類の店舗と, それらが中心地区と中 心商店街に占める割合を示した。中心部代位置する基町, 本仃の闭地区では, 楽器店の大部分, 時䑒, 眼 鏡や写真機店の半ば近くが集中し，ついで運動具，交具類の順序となる。

さらに，これら両地区内の中心商店街である本町，銀座，金座および，それらの脇通りについて，店舗 の集中状況を検討すると，楽器店を恋ず第一とし，ついで，時計，眼鏡の順となり，以下玩具㧍よび娛楽 用品, 運動具, 書籍, 写真機具, 紙, 交具, 化粧品, 医薬品とつづく。

それ故, 都市構造に反映せる歒店街への店舗の構成の仕方, 抢よび店舗の性格による集中度といつたこ

* 交部省初等中等敎育局 
第 1 表 伊豆下田町に扣ける商店街の店舗構成（昭和 26 年 1 月現在）

\begin{tabular}{|c|c|c|c|c|c|c|c|c|c|c|c|}
\hline 商店街 & 乾 & $\begin{array}{l}\text { 青 } \\
\text { 果 }\end{array}$ & $\begin{array}{l}\text { 菓 } \\
\text { 子 }\end{array}$ & $\begin{array}{l}\text { 䭾 } \\
\text { 菒 } \\
\text { 子 }\end{array}$ & 雑 & 時 & 琵 & $\begin{array}{l}\text { 览 } \\
\text { 草 } \\
\text { 店 }\end{array}$ & $\begin{array}{l}\text { 领喫 } \\
\text { 食茶 }\end{array}$ & $\begin{array}{l}\text { 與 } \\
\text { 服 }\end{array}$ & $\begin{array}{l}\text { 洋 } \\
\text { 品 }\end{array}$ \\
\hline 町 全 体 & 21 & 27 & 16 & 25 & 8 & 10 & 16 & 8 & 21 & 8 & 5 \\
\hline 下田 銀 座 & 3 & 5 & 2 & 2 & 1 & 3 & 4 & 1 & 4 & 2 & 0 \\
\hline 伊 勢 銀 座 & 1 & 0 & 1 & 2 & 0 & 4 & 1 & 0 & 0 & 2 & 2 \\
\hline 東部商店会 & 8 & 5 & 4 & 5 & 2 & 1 & 3 & 1 & 6 & 3 & 1 \\
\hline 3 商店街の計 & 12 & 10 & 7 & 9 & 3 & 8 & 8 & 2 & 10 & 7 & 3 \\
\hline
\end{tabular}

第 2 表 広島市に扣ける地区別にみた交化品の分布（墑業統計調查 31 年度）

\begin{tabular}{|c|c|c|c|c|c|c|c|c|c|c|c|}
\hline & & $\begin{array}{l}\text { 医 } \\
\text { 菂 } \\
\text { 品 }\end{array}$ & $\begin{array}{l}\text { 化 } \\
\text { 粧 } \\
\text { 品 }\end{array}$ & $\begin{array}{l}\text { 畫 } \\
\text { 籍 }\end{array}$ & $\begin{array}{l}\text { 紙 }^{\text {文 }} \\
\text { ・具 }\end{array}$ & $\begin{array}{l}\text { 運 } \\
\text { 動 } \\
\text { 具 }\end{array}$ & $\begin{array}{l}\text { 玩娛品 } \\
\text { 具楽 } \\
\text { - 用 }\end{array}$ & $\begin{array}{l}\text { 楽 } \\
\text { 器 }\end{array}$ & $\begin{array}{l}\text { 写 } \\
\text { 真 } \\
\text { 機 }\end{array}$ & $\begin{array}{l}\text { 時眼 } \\
\text { 計鏡 } \\
\text { • 類 }\end{array}$ & $\begin{array}{l}\text { そ } \\
\text { の } \\
\text { 他 }\end{array}$ \\
\hline 基 & 町 & 19 & 18 & 7 & 28 & 4 & 5 & 3 & 7 & 23 & 12 \\
\hline 本 & 庁 & 32 & 24 & 9 & 29 & 6 & 7 & 2 & 13 & 21 & 16 \\
\hline 皆 & 実 & 8 & 5 & 0 & 12 & 2 & 4 & 0 & 3 & 3 & 8 \\
\hline 十日 & 市 & 23 & 25 & 7 & 17 & 1 & 2 & 0 & 4 & 9 & 19 \\
\hline 段 & 原 & 27 & 17 & 14 & 13 & 6 & 8 & 2 & 9 & 20 & 13 \\
\hline 己 & 斐 & 14 & 11 & 2 & 7 & 2 & 3 & 0 & 2 & 6 & 3 \\
\hline 比 治 & 山 & 9 & 2 & 4 & 10 & 2 & 2 & 0 & 1 & 0 & 1 \\
\hline 宇 & 治 & 10 & 11 & 4 & 11 & 3 & 4 & 0 & 2 & 5 & 4 \\
\hline 草 & 津 & 6 & 4 & 1 & 8 & 1 & 1 & 0 & 1 & 2 & 3 \\
\hline 尾 & 長 & 8 & 3 & 3 & 7 & 0 & 0 & 0 & 1 & 1 & 8 \\
\hline 牛 & 田 & 3 & 3 & 0 & 5 & 0 & 1 & 0 & 0 & 0 & 1 \\
\hline 青 & 崎 & 6 & 1 & 3 & 8 & 0 & 2 & 0 & 1 & 1 & 1 \\
\hline 大 & 河 & 6 & 2 & 3 & 6 & 0 & 1 & 0 & 0 & 3 & 1 \\
\hline 舟 & 入 & 5 & 8 & 1 & 8 & 1 & 0 & 0 & 1 & 2 & 1 \\
\hline 仁 & 保 & 3 & 0 & 0 & 2 & 0 & 0 & 0 & 0 & 0 & 0 \\
\hline 中 & $山$ & 0 & 0 & 0 & 0 & 0 & 0 & 0 & 0 & 0 & 0 \\
\hline 似 & 島 & 2 & 1 & 0 & 0 & 0 & 0 & 0 & 0 & 0 & 0 \\
\hline 戸 & 坂 & 0 & 0 & 0 & 0 & 0 & 0 & 7 & 0 & 0 & 0 \\
\hline (合言) & & 201 & 155 & 64 & 188 & 29 & 43 & 7 & 48 & 101. & 96 \\
\hline $\begin{array}{l}\text { 基町・本 } \\
\text { 地区 }\end{array}$ & 朾 & $25 \%$ & $27.1 \%$ & $25 \%$ & $30 \%$ & $34.5 \%$ & $27.9 \%$ & $71 \%$ & $41.7 \%$ & $43.5 \%$ & $29.2 \%$ \\
\hline
\end{tabular}

とを知りらるであろら，

2. 都市規模と中心商店街の店舗

都甫人口によつて，その中心商店街の店舗構成は，ぞのように変化するであろらかということが問題と なる。すなわち，小都市における中心商店街と大都市におけるとれとでは，顧客の購賃力に差があるため に，おのずから，そこに立地する店舗には，質的な相違が生れるはずである。ここでは，突地調査による 20 都市の中心商店街の店舗構成を第 3 表に揭げ，以下に検討する。

東京, 大阪, 横浜などの巨大都市ならびに, 福岡, 広島, 静岡などの大都甫の中心滴店街で, ことさら 店舗の数が多く指摘されるものとしては, 単価の高い商品で, しかも容積の小さいものを販売している店 舗であり，袋物，時計，眼鏡，服飾，美術工芸品，写真機具などの專業店舗がこれに相当する。このう 
第 3 表中心商店街の店舖構 成 (昭和 29 年 8 月現在)

\begin{tabular}{|c|c|c|c|c|c|c|c|c|c|c|c|c|c|c|c|c|c|c|c|c|c|}
\hline 心商店街 & $\begin{array}{l}\text { 洋 } \\
\text { 服 } \\
\text { 服 } \\
\text { 地 }\end{array}$ & $\mid \begin{array}{c}\text { 洋 } \\
\text { 品 } \\
\text { 雑 } \\
\text { 貨 }\end{array}$ & 服 & 物 & \begin{tabular}{|c|} 
時 \\
計 \\
眼 \\
鏡 \\
\end{tabular} & 子। & 食 & $\begin{array}{l}\text { 食 } \\
\text { 料 }\end{array}$ & $\mid$\begin{tabular}{c|} 
書 \\
籍 \\
交 \\
具 \\
\end{tabular} & \begin{tabular}{c|} 
薬 \\
・ \\
化 \\
粧
\end{tabular} & 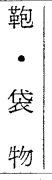 & $\left|\begin{array}{l}\text { 洋 } \\
\text { 傘 } \\
\text { 毛 } \\
\text { 糸 }\end{array}\right|$ & \begin{tabular}{c|} 
楽 \\
器 \\
写 \\
真
\end{tabular} & \begin{tabular}{|c|} 
金 \\
物 \\
荒 \\
物
\end{tabular} & \begin{tabular}{l|} 
工 \\
芸 \\
$\dot{0}$ \\
美 \\
術
\end{tabular} & $\begin{array}{l}\text { 電 } \\
\text { 気 } \\
\text { 器 } \\
\text { 具 }\end{array}$ & \begin{tabular}{l|} 
玩 \\
具 \\
運 \\
動 \\
具
\end{tabular} & 茶| & & 品 & 他 \\
\hline 東京銀座 $5 \cdot 6 \cdot 7$ & 6 & 8 & 0 & 5 & 10 & 6 & 2 & 2 & 0 & 0 & 9 & 2 & 2 & $0^{\prime}$ & 2 & 0 & 0 & 3 & 0 & 4 & 17 \\
\hline 橋 2 & 12 & 8 & 6 & 5 & 10 & 3 & 1 & 2 & 2 & 1 & 5 & 5 & 2 & 0 & 4 & 0 & 0 & 3 & 0 & 0 & 20 \\
\hline 横浜伊勢佐木 $4 \cdot 5$ & 17 & 7 & 1. & 5 & 6 & 3 & 2 & 4 & 0 & 2 & 2 & 1 & 4 & 2 & 5 & 0 & 2 & 2 & 0 & 2 & 8 \\
\hline 寿通り & 7 & 10 & 6 & 2 & 2 & 3 & 1 & 1 & 2 & 5 & 2 & 3 & 0 & 0 & 5 & 0 & 1 & 2 & 2 & 1 & 13 \\
\hline 広島本町 $1 \cdot 2$ & 7 & 6 & 5 & 6 & 5 & 0 & 3 & 3 & 3 & 1 & 1 & 3 & 2 & 1 & 2 & 3 & 2 & 1 & 3 & 1 & 20 \\
\hline 服 2 & 8 & 5 & 2 & 4 & 6 & 2 & 5 & 4 & 6 & 3 & 3 & 4 & 1 & 1 & 1 & 1 & 4 & 0 & 0 & 2 & 17 \\
\hline 頛通り & 7 & 5 & 6 & 5 & 3 & 1. & 8 & 1 & 3 & 2 & 0 & 4 & 2 & 0 & 0 & 2 & 1 & 3 & 0 & 0 & 22 \\
\hline & 13 & 7 & 7 & 3 & 3 & 3 & 0 & 0 & 3 & 1 & 2 & 4 & 1 & 1 & 3 & 1 & 3 & 1 & 0 & 0 & 20 \\
\hline ブラクリ & 10 & 13 & 5 & 5 & 3 & 5 & 2 & 5 & 0 & 3 & 5 & 1 & 1 & 2 & 1 & 1 & 4 & 0 & 0 & 1 & 9 \\
\hline 下之町 & 6 & 5 & 4 & 4 & 1 & 6 & 5 & 1 & 6 & 1 & 2 & 3 & 2 & 0 & 2 & 1 & 3 & 1 & 0 & 1 & 7 \\
\hline 與中通り & 10 & 7 & 1 & 7 & 6 & 3 & 4 & 1 & 2 & 1 & 4 & 1 & 5 & 1 & 0 & 1 & 0 & 0 & 0 & 0 & 8 \\
\hline 高知带屋町 2 & 17 & 8 & 7 & 4 & 0 & 2 & 4 & 0 & 6 & 2 & 2 & 3 & 0 & 4 & 0 & 1 & 0 & 1 & 0 & 1 & 10 \\
\hline 甲府銀座 & 12 & 8 & 4 & 5 & 3 & 2 & 5 & 3 & 2 & 2 & 3 & 1 & 0 & 1 & 1 & 2 & 0 & 0 & 0 & 0 & 11 \\
\hline 央銀座 & 9 & 8 & 6 & 3 & 1 & 6 & 5 & 6 & 5 & 3 & 2 & 0 & 2 & 1 & 1 & 0 & 4 & 1 & 4 & 1 & 24 \\
\hline & 2 & 7 & 0 & 2 & 1 & 5 & 4 & 4 & 2 & 5 & 0 & 0 & 0 & 4 & 0 & 3 & 1 & 1 & 2 & 0 & 20 \\
\hline & 12 & 8 & 4 & 6 & 4 & 2 & 1 & 5 & 4 & 6 & 2 & 2 & 1 & 2 & 2 & 5 & 1 & 0 & 2 & 2 & 23 \\
\hline E町 & 2 & 7 & 1 & 2 & 5 & 4 & 2 & 5 & 3 & 4 & 0 & 1 & 1 & 6 & 1 & 1 & 0 & 0 & 4 & 0 & 19 \\
\hline 吉桜通り & 6 & 9 & 11 & 3 & 3 & 1 . & 2 & 1 & 1 & 6 & 1 & 4 & 3 & 3 & 0 & 4 & 0 & 0 & 0 & 0 & 9 \\
\hline 宇和島新橋袋町 & 9 & 8 & 10 & 5 & 2 & 2 & 1 & 3 & 1 & 2 & 4 & 0 & 1 & 2 & 1 & 2 & 1 & 0 & 1 & 0 & 20 \\
\hline 新宮仲之町 & 7 & 11 & 8 & 2 & 1 & 4 & 2 & 4 & 4 & 4 & 1 & 3 & 4 & 1 & 0 & 2 & 0 & 0 & 0 & 0 & 16 \\
\hline & & & & 83 & 75 & 63 & & 55 & 55 & 54 & 50 & 45 & & 32 & 31 & 30 & 27 & 19 & 18 & & \\
\hline
\end{tabular}

ち, 特に注目される専用店舗としては, 吳服が専門化されて, ある特定の織物のみを取披う店舗が現われ たり, 洋品雑貨商が分化して, ネクタイ, 靴下の各専門店舗が生じたり, 宝石, 扇, 婦人靴, 純契茶など が存在する。

これに対して, 姬路, 高知などの中都市や福山, 松汇などの小都市の中心商店街に共通して数多く存在 する金物，荒物，家具調度，電気器具などの店舖は，大，巨大都市の中心商店街では，ほとんど見られな い。したがつて, この点では, 小, 中都市の店舗構成と, 大, 巨大都市の店舗棈成との間では, 対蹠的な 傾向を示すこととなる。

一方, いずれの都市の中心商店街を通じても, 普遍的に立地する店舗として, 洋品雑貨, 洋服服地, 履 物, 菓子, 食料品, 洋傘, ショール, 毛系, 楽器などの店舗が指摘される。

\section{II. 中心商店街における店舗の配置}

上に述べてきた如く, 商業機能の重要なる通りにおいては, 商品のかさが小さくて, 質の高いものが販 売されているが，これは店舗の占める地価の高騰のためかかる現象が, 店舗への反映となり, 中心商店街 を構成する売場面積の間口に対する奥行の割合となつて現われたものといえよう。そこで，中心商店街の 活舗の売場面積およびその閒口対奥行の比について検討したい。 
1. ここで, 売場面積と呼ぶの は, 通常商品を陳列し，そこで顧 客师売する場所を指すものであ り，場合によつては，販売場所の 奥に事務所を兼ねたものもある。 したがつて, 悠密な意味での売場 面積を測定することは，中々容易 なことではない。

調查困難なるサービス業に属す る娛楽, 食堂, 理坺店, 写真館な ぞを一応除外した。このようにし て, 実地調查にもとずく, 都市每 の売場面積および間口対奥行の割 合を第 4 表に揭げた6)。

まず，各都市の中心商店街に特 ける売場面積についてみると, 東 京銀座の平均 25.8 坪をはじめと し,つづいて, 大服心斎橋筋の17.3 坪，広島本町筋の 14.2 坪は大き く, 扮拈む祄小都市化向了につれ て, 店舗の売場面積が小さくなつ ていることが看取される。これに ついては，店舗が大企業化されれ ばされるほど，それだけ純売上高 が増加するという資本主義経済の 一般的通念に上るものとい方上 5 。

したがつて，一般の常識では， 大都市の中心嘀店街では，墑店は 通りに制約されて, 売場面積も, 小都市のそれに比へていさくなつ ているといら考光を裏切るるので ある。

ついで, 店鋪の売場面積につい て, 閒口と奥行との比をみると, 東京銀应，大服心脐橋筋の間口 1 に対する奥行 1.9 倍を筆頭に，広 島の本町筋 1.2 丁目の 1.5 倍, 和 歌山ブラクリ通りの間口 1 亿封する奥行 1.4 倍, 只中通りの 1.3 倍, 同じく, 烃江京町の 1.3 倍などが指 摘される。

また，市制ブームによつて生じた行田，本庄の雨市は，間口と奥行とは，括拈むね同じ比率をとり，伊 豆下田町は，間口に対して奥行は 0.8 の質をとり，拉よそ奥行が間口に対する割合が +1 を越光るとき，

\begin{tabular}{|c|c|c|c|c|c|c|}
\hline & 都市の中心商店街 & $\begin{array}{c}\text { 舆 行 } \\
\text { (間) }\end{array}$ & $\begin{array}{c}\text { 間 口 } \\
\text { (間) }\end{array}$ & 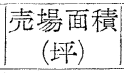 & $\begin{array}{l}\text { 奥行 } \\
\text { 間口 }\end{array}$ & 店舗数 \\
\hline 1. & 東京銀座 & 6.6 & 3.5 & 25.8 & 1.9 & 135 \\
\hline 2 . & 大阪心斎橋 & 5.2 & 2.8 & 17.3 & 1.9 & 141 \\
\hline 3. & 広島本通り & 3.1 & 4.6 & 14.2 & 1.5 & 78 \\
\hline 4 . & 和歌山ブラクリ & 3.4 & 2.4 & 8.2 & 1.4 & 83 \\
\hline 5 . & 呉中通 D & 3.3 & 2.5 & 8.3 & 1.3 & 97 \\
\hline 6 . & 高崎紺屋町 & 3.2 & 2.8 & 9.1 & 1.1 & 60 \\
\hline 7 . & 松江京町 & 3.7 & 2.9 & 13.0 & 1.3 & 40 \\
\hline 8. & 鳥取若桜 & 3.1 & 3.4 & 10.5 & 1.1 & 63 \\
\hline 9 . & 水戸南町 & 3.4 & 3.1 & 10.5 & 1.1 & 62 \\
\hline 10. & 岩国銀座 & 3.4 & 3.3 & 11.2 & 1.0 & 70 \\
\hline 11 . & 新宮仲町 & 2.7 & 2.4 & 6.5 & 1.1 & 93 \\
\hline 12 . & 石岡本町 & 3.1 & 3.0 & 9.3 & 1.03 & 71 \\
\hline 13. & 行田本町 & 2.4 & 2.5 & 6.0 & 0.98 & 42 \\
\hline 14. & 本庄本町 & 2.8 & 2.8 & 7.8 & 0.98 & 50 \\
\hline 15 . & 下田銀座 & 2.5 & 3.2 & 8.0 & 0.8 & 53 \\
\hline
\end{tabular}

第 5 表 東京市域に扣ける商店街の店舖について

(29 年 9 月現在)

\begin{tabular}{|c|c|c|c|c|c|}
\hline 都市の中心商店街 & $\begin{array}{c}\text { 奥 行 } \\
\text { (閒) }\end{array}$ & $\begin{array}{c}\text { 間 口 } \\
\text { (間) }\end{array}$ & 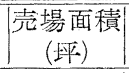 & $\begin{array}{l}\text { 奥行 } \\
\text { 間口 }\end{array}$ & 店舖数 \\
\hline 座 & 6.6 & 3.5 & 25.8 & 1.9 & 135 \\
\hline 新宿中央通り & 6.6 & 2.7 & 17.1 & 2.4 & 83 \\
\hline 渋谷道玄坂 & 4.8 & 2.5 & 11.8 & 1.8 & 101 \\
\hline 池 袋 西 口 & 3.9 & 2.2 & 8.5 & 1.8 & 209 \\
\hline 人 形 町 & 3.5 & 1.9 & 8.5 & 1.8 & 77 \\
\hline 上 野 & 6.4 & 2.9 & 13.7 & 2.2 & 109 \\
\hline 麻布十番通り & 4.6 & 2.9 & 6.9 & 1.6 & 67 \\
\hline 巣鴨地蔵通り & 4.1 & 2.7 & 6.9 & 1.5 & 118 \\
\hline 大井 銀 座 & 3.5 & 2.2 & 5.6 & 1.6 & 87 \\
\hline 武 蔵 小 山 & 4.1 & 2.6 & 9.2 & 1.5 & 97 \\
\hline 三軒 茶屋 & 2.8 & 2.2 & 5.1 & 1.3 & 173 \\
\hline 荻窪北口通り & 3.2 & 2.7 & 7.9 & 1.2 & 84 \\
\hline 十条銀座 & 2.9 & 2.7 & 7.8 & 1.1 & 126 \\
\hline 小 岩 & 2.7 & 2.3 & 6.3 & 0.9 & 148 \\
\hline 中 野 北 口 & 3.5 & 2.3 & 6.5 & 1.3 & 111 \\
\hline
\end{tabular}


第 6 表 大阪心斎橋筋の店舖について

\begin{tabular}{|c|c|c|c|c|c|}
\hline & $\begin{array}{c}\text { 舆 行 } \\
\text { (間) }\end{array}$ & $\begin{array}{c}\text { 間 口 } \\
\text { (間) }\end{array}$ & $\mid \begin{array}{c}\mid \text { 売場面積 } \\
\text { (坪) }\end{array}$ & $\begin{array}{l}\text { 奥行 } \\
\text { 間口 }\end{array}$ & 店舖数 \\
\hline 呉服 & 5.1 & 3.5 & 17.7 & 1.5 & 10 \\
\hline 紳 士 服 & 4.8 & 2.6 & 12.6 & 1.8 & 10 \\
\hline 婦人・子供服 & 5.7 & 2.7 & 15.4 & 2.1 & 20 \\
\hline 身辺雑貨 (A) & 8.2 & 2.8 & 22.9 & 2.9 & 20 \\
\hline 身辺雑貨 (B) & 4.9 & 2.4 & 11.7 & 2.4 & 16 \\
\hline 和 洋家 具 & 5.1 & 2.3 & 11.7 & 2.2 & 3 \\
\hline 食 料 品 & 4.4 & 2.4 & 10.5 & 1.8 & 9 \\
\hline 家庭周品 & 4.4 & 2.9 & 12.9 & 1.5 & 10 \\
\hline 趣 味 品 & 7.2 & 4.0 & 28.8 & 1.8 & 7 \\
\hline 医薬・化粧 & 4.0 & 2.5 & 10.0 & 1.6 & 5 \\
\hline 書籍・文具 & 3.8 & 2.6 & 9.9 & 1.5 & 7 \\
\hline 時計・眼鏡 & 8.5 & 2.6 & 22.2 & 3.3 & 12 \\
\hline 飲 食 店 & 8.8 & 3.2 & 28.2 & 2.8 & 12 \\
\hline 總＼cjkstart合 & 6.2 & 2.8 & 17.3 & 2.2 & 141 \\
\hline
\end{tabular}

大阪商工会議所（昭和 27 年 2 月調查）
獄店街のもつ通りの商業機能の重要性 が都市的なものとして, 重要視される ベきであろらか。

2.つぎに，かかる店赤の売場面 積, 間口対奥行の関係を, 大東京の谷 地域の敵店街について検討しょ5 ${ }^{7}$ 。

第 5 表に示すように, 東京銀座の売 場面積の平均 25.8 坪を簍頭に，つい で, 新宿中央通りの 17.1 坪となるが, これは前揭の大阪心斎橋筋の売場面積 の平均坪数に相当するものである。

上野商店会に属する店舗の平均売場 面積は，13.7坪となり，渋谷道立坂の 11.8 坪, 新興の盛場池袋の西口は, 8.5 坪を示す。

その他，環状線ならびに中央線沿線 の二次的, 三次的盛場では売場面積は 6〜7 坪となる。

ついで，売場面積の間口対奥行の比を検討すると，新宿中央通りの間口 1 に対する奥行 2.4 をはじめ, 上野 2.2 , 東京銀座 1.9 を示す。ここで問題となるのは，売場面積の間口対奥行の割合が銀座に対して，新 宿，上野などの方が大きいということである。

これについては, 売場面積の大小と関係してくるむのであり, 必ずしも間口に対する奥行の大, 小と通

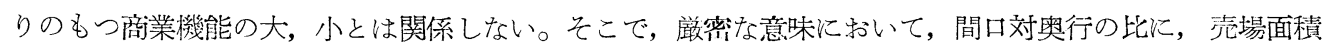
の絶詨值を考慮して, 通りのもつ商業的価值を判断すべきであろう。

ところで，東京の二次的商店街である㮺鴨地蔵通り，武蔵小山，大井銀座などは，間口に対する奥行の 割合は，1.5〜1.6 倍を示し，さらに，対外地域では，1.1〜1.2 倍となる。この事害からわかるように，打

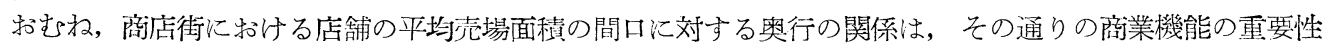
を裏蓃さする1つの指標ともいえるであるう。

3.さらに, 店舗の売場面積を店舗の業積との関係に扰いて検討してみたい。この 1 例として，大阪甫 の中心商店街である心斑橋筋について, 第 6 表に揭げた。売場面積の平均值がもつとも高いのは, 趣味品 を販売する店舗の 28.8 坪や, 飲食店の 28.2 坪をはじめ, 和装, 洋装の衣料雑貨である身辺雑貨 $\mathrm{A}$, の 22.9

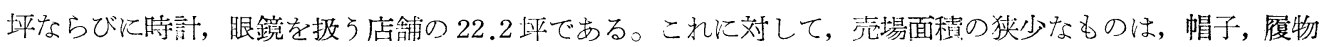
などを扱う身辺雑貨 $\mathrm{B}$, 和洋家具, 食料品, 医薬化粧品などであり，どちらかとい壳ば，小都方の中心摘 店街または，大都市の二次的率店街において構成されている店舗である。

では，これらの店舗の平均売場面積に対する間口の奥行との関係を指摘すると，むず，時計，眼鏡の平 均間口 1 亿対する奥行の 3.3 倍, 和装, 洋装の衣料雑貨を主とする身辺雑貨 $\mathrm{A}$ 抢よび飲食店の間口 1 に対 する奥行の 2.8 倍などが揭げられる。

これに対して, 平均売場面積の小さい紳土服, 身辺雑貨 $\mathrm{B}$, 和洋家具, 食料品, 医薬化粧品, 家庭用品 などは，身辺雑貨 Bを除いては，おお执むね，平均売場面積の間口に対する奥行の割合も狭少となる。

売場面積の広いものは, 結局大企業経営によつて利潤を増すこととなり，かかる店舗は，交化品などの 買迴り品を主とするため，間口に対して奥行を必要とする売場面積の型態をとるものといえよう。したが 
つて，売場面積の大小，筫迥りの品の有無は閒口と奥行との 関倸をある程度迄替定するものといらことが 出来る。

第 7 表中心商店街 と百貨店

\begin{tabular}{|c|c|c|c|c|c|c|c|c|c|c|}
\hline 都 市 & \begin{tabular}{|l|} 
D.S. 協 \\
会会翼店
\end{tabular} & 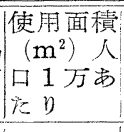 & $\begin{array}{l}\text { 売上高仙 } \\
\text { 人口 } 1 \text { 人 } \\
\text { あたり }\end{array}$ & $\mid \begin{array}{l}\text { 中心商店 } \\
\text { 街とデパ } \\
\text {-トの位 } \\
\text { 置 }\end{array}$ & 都 市 & 市 & $\begin{array}{l}\text { D.S. 協 } \\
\text { 会会高店 }\end{array}$ & 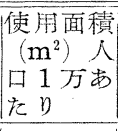 & $\begin{array}{l}\text { 荒上高円 } \\
\text { 人口 } 1 \text { 人 } \\
\text { あた }\end{array}$ & 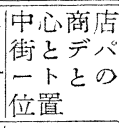 \\
\hline 6 大都尚 & 39 & & & & 10万以 & & 26 & & & \\
\hline 東 京 & 15 & 526.6 & 110.5 & & 豊 標 & 橋 & 1 & 113.5 & 17.8 & c. \\
\hline 阪 & 10 & $1,337.6$ & 236.6 & & 千 & 葉 & 1 & 143.3 & 31.5 & b. \\
\hline 京 都 & 4 & 645.3 & 104.9 & & 德 & 島 & 1 & 248.2 & 22.3 & b. \\
\hline 名古屋 & 3 & 741.8 & 98.2 & 冫 & 秋 & 昍 & 1 & 139.0 & 36.9 & b. \\
\hline 横 浜 & 3 & 211.8 & 327.4 & & 宮 & 崎 & 2 & 576.1 & 79.5 & \\
\hline 神 & 4 & 656.8 & 100.8 & & 高 & 松 & 1 & 403.7 & 60.7 & a. \\
\hline 30 万以上 & 10 & & & & 門 & 司 & 1 & 320.4 & 49.8 & \\
\hline 福岡 & 3 & $1,345.8$ & 201.8 & & 旭 & 川 & 1 & 194.9 & 44.9 & \\
\hline 仙 & 3 & 526.4 & 100.8 & & 甲 斤 & 府 & 1 & 349.5 & 44.3 & b. \\
\hline 㥓 & 1 & 61.1 & 18.5 & & 久留 & & 1 & 632.7 & 59.0 & d. \\
\hline 幌 & 3 & 877.0 & 177.2 & & 盛闹 & 岡 & 2 & 331.3 & 51.4 & \\
\hline 20 万以上 & 20 & & & & 高 & 岡 & 1 & 318.7 & 31.2 & a. \\
\hline 広島 & 1 & 369.4 & 45.9 & a. & 室 & 蘭 & 1 & 207.3 & 24.9 & \\
\hline 本 & 3 & 763.4 & 151.1 & a. a. b. & 青 并 & 森 & 1 & 248.0 & 36.0 & d. \\
\hline 金沢 & 1 & 370.6 & 38.0 & b. & 宇都官 & 宮 & 1 & 235.1 & 52.5 & b. \\
\hline 横 須 賀 & 1 & 279.6 & 27.0 & & 八 $\bar{F}$ & 户 & 1 & 157.3 & 16.8 & d. \\
\hline 長 槣 & 2 & 514.3 & 55.3 & & 福 & 井 & 1 & 392.2 & 56.7 & b. \\
\hline 青静揇 & 2 & 487.5 & 54.9 & a. c. & 沼 垹 & 津 & 1 & 143.0 & 35.2 & \\
\hline 鹿 览 島 & 2 & 796.1 & 93.3 & a. a. & 5 万以 & & 14 & & & \\
\hline 㥛 館 & 2 & 588.8 & 76.1 & a. & 大 分 & 分 & 1 & 890.5 & 174.3 & a. \\
\hline 潟 & 2 & 611.7 & 92.3 & a. a. & 福 & 島 & 1 & 237.4 & 43.4 & d. \\
\hline 阜 & 2 & 371.4 & 39.9 & a. c. & 釧 & 路 & 1 & 404.6 & 71.5 & \\
\hline 姬路 & 2 & 462.3 & 37.8 & a. d. & 若 & 松 & 1 & 376.3 & 41.8 & \\
\hline 15 万以上 & 12 & & & & 大 & 坦 & 1 & 181.5 & 14.6 & d. \\
\hline 小 倉 & 2 & $1,530.0$ & 221.0 & a. b. & 山 & 口 & 1 & 443.3 & 41.3 & \\
\hline 佐世保 & 1 & 319.6 & 58.3 & a. & 倉 & 敷 & 1 & 114.7 & 12.9 & c. \\
\hline 下 関 & 1 & 242.1 & 44.8 & d. & 福 & 4 & 1 & 336.4 & 39.7 & c. \\
\hline 大牟时 & 1 & 374.4 & 33.7 & d. & 佐 & 賀 & 1 & 484.2 & 108.3 & b. \\
\hline 和歌山 & 1 & 340.1 & 53.5 & a. & 弘 & 前 & 1 & 538.1 & 51.1 & \\
\hline 阔出 & 1 & 670.8 & 90.9 & b. & 鳥 & 取 & 1 & 372.6 & 48.7 & c. \\
\hline 樽 & 2 & 508.6 & 56.7 & & 飯 & 塚 & 1 & 339.1 & 226.0 & b. \\
\hline 山 & 1 & 148.7 & 39.4 & a. & & & & & & \\
\hline 松 & 1 & 419.7 & 35.2 & d. & & & & & & \\
\hline 山 & 1 & 484.1 & 56.1 & d. & & & & & & \\
\hline
\end{tabular}

使用面積・売上高は日本 D.S. 協会の調查による, 昭和 29 年末あるいは 29 年中の計算 


\section{III. 中心商店街における小売商としての百貨店}

都市規模の堌大につれて，中心商店街に怙ける小売店埔は，一般には次第に専業化されてくるといらこ とについてはすでに述べてきたが，これは百貨店の大企業化の傾向とね，相関係して生じるものである。

この解釈として考光られることは, 百貨店というものの本質からいつて, 必ずしも単独の店舗の如き専 門化には至らない場合が多いからであり, それ故, 百貨店への競合関係においては，店舖の専業化によつ て，これに対応することがもつとも好ましい。

ところで, 百貨店は, 別名, 繸の中心商店街であると呼ばれている点で, その立地点の如何が問題にな る。これと共に, 都市規模, 都市機能などが篦係してくる。第 7 表は, 都市デパートの数と売場面積および 人口 1 人あたりの売上高などを揭示した。まず,デパートの売場岼数を都市人口で除して，人口 1 万あたり の平数を算出した。これによると, 抒扔むね, 都市人口に相対して, 百貨店がごの程度の重要性をもつてい るかということ，いいか觉れば，都市の市民のデパート光の関心の程度を知りうることになるであろら。 かつる傾向の顕著なる都市としては, 大分, 久留米, 党崎, 岡山, 小倉, 新潟, 鹿児島, 熊本, 札幌,

第 8 表都市 9 後背地人口率

\begin{tabular}{|c|c|c|c|c|}
\hline $\begin{array}{l}\text { 後背地人口率 } \\
\text { 都市人口 }\end{array}$ & 2.0 以上 & $1.9 \sim 1.5$ & $1.4 \sim 1.0$ & 0.9 以下 \\
\hline 100 万以上 & 東京, 大阪 & $\begin{array}{l}\text { 京都, 名古屋, } \\
\text { 横浜, 神戸 }\end{array}$ & & \\
\hline 30 万以上 & 福岡, 札幌 & 広島, 仙台 & 横須賀，川崎 & 尼崎 \\
\hline 20 万以上 & 小倉, 佐世保 & $\begin{array}{l}\text { 熊本, 長崎 } \\
\text { 金沢, 八幡 } \\
\text { 鹿睍島, 岐阜 } \\
\text { 新潟, 岡山 }\end{array}$ & $\begin{array}{l}\text { 静岡, 恛館, 姬路 } \\
\text { 下関, 和歌山 }\end{array}$ & 堺 \\
\hline 15 万以上 & 小樽, 浜松 & 富山 & $\begin{array}{l}\text { 大厸田, 呉, 松山 } \\
\text { 高知, 豊橋 }\end{array}$ & 大津, 西宮, 布施 \\
\hline 10 万以上 & 宇都宮, 高岡 & $\begin{array}{l}\text { 千葉, 高松 } \\
\text { 秋四, 甲府 } \\
\text { 旭川, 盛岡 } \\
\text { 久留米, 室闌 } \\
\text { 青森, 長野 } \\
\text { 釧路, 前橋 } \\
\text { 高崎 }\end{array}$ & $\begin{array}{l}\text { 德島, 宇部, 門司 } \\
\text { 四日市, 宮崎, 浦和 } \\
\text { 川口, 市川, 沼津 } \\
\text { 山形, 大亮, 八戸 } \\
\text { 夕張 }\end{array}$ & 岸和田, 明石 \\
\hline 5 万以上 & $\begin{array}{l}\text { 大分, 松本 } \\
\text { 八王子, 水戸 } \\
\text { 佐賀, 飯塚 } \\
\text { 帯広, 立川 } \\
\text { 津山 }\end{array}$ & $\begin{array}{l}\text { 福島, 若松, 小田原 } \\
\text { 松江, 長岡, 武蔵野 } \\
\text { 一宮, 宇治山旺 } \\
\text { 福山, 会津若松 } \\
\text { 鳥取, 尾道, 米子 } \\
\text { 酒田, 直方, 川越 } \\
\text { 平塚, 石巻, 唐津 } \\
\text { 松阪 }\end{array}$ & 略 & 省 \\
\hline
\end{tabular}

拙稿 都市の被業機能より(都市問题研究 (1956) 8 卷 3 号) 
福岡，大阪などがあげられる。これらの中，2・3を除く大部分の都市が九州であるということに注目すべ きであろら。

人口 1 人当りの百貨店の売上高と，さきにみてきた人口 1 万人当りの使为面積との相関を検討すると著 しく高い。すなわら, 各都市の人口 1 万人あたりの使肘面積が広くなればなるほどその都市における人口 1 人あたりの売上高が高くなつていることであり，この事実は，企業の大資本化による利潤の增版もと ずくものと考えられる。

では，デパートの使用面積と 1 人あたりの売上高の割合とが著しい都市について，さらに都市で消費さ れる商業機能との関係を検討したい。

第 8 表は，各都市で消費される小売金額から逆算した後背地を含めた人口を計算した。

このようにして，都市地域とその後背地域との比率を求め9 , 上述した百貨店の 1 人当りの觉上高との関 係を検討すると，招招む权一致の傾向をとることが看取される。

この事笑は，都术の中心谪店街の繁華さを裏書さするものとなる。

ところで，百貨店は中心商店街に拈ける立地の如何によつて，どのようなことがい光るものであろうか そついて前揭の 7 表に示した。いま, 人口 30 万以下の备都市の百貨店の位置をつぎの 4 通りと分けること

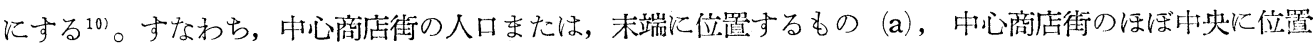
するもの (b), 中心商店街に直接のぞんでいないもの (c)，あるいは，主要交通機関の近くにあるもの (d) 飞分類することが出来る。

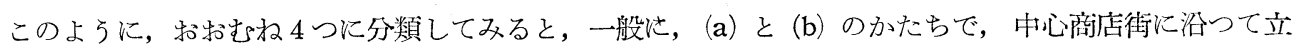
地している百貨店の存在する都市は，百貨店の使用面積に対する売上高が同一の都市㚘模において高いと いうことが指摘出来る。

ただし，かかる傾向も，すべてに適応されるものではなく，たとえば，中心裥店街の入口に立地する広 島术の金座街と金沢市の片町商店街の中央位置する百貨店などは，この限りではない。

これに対して, 中心商店街から離れた官庁街や, その他に立地するもの, 拉よび駅前に存在するもので は，全般的に人口 1 人当りの売上高が低く示されている。ただし， $\mathrm{d}$ 型に相当するものでも，ターミナル デパートに関しては, この限りではない。

\section{IV. 中心商店街における店舗の変質}

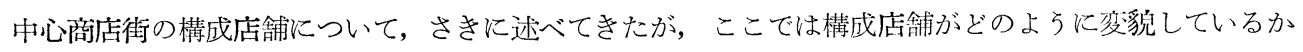
第 9 表 東京銀座通 9 店舖構成の変化 （自大正 10 年 至昭和 25 年)

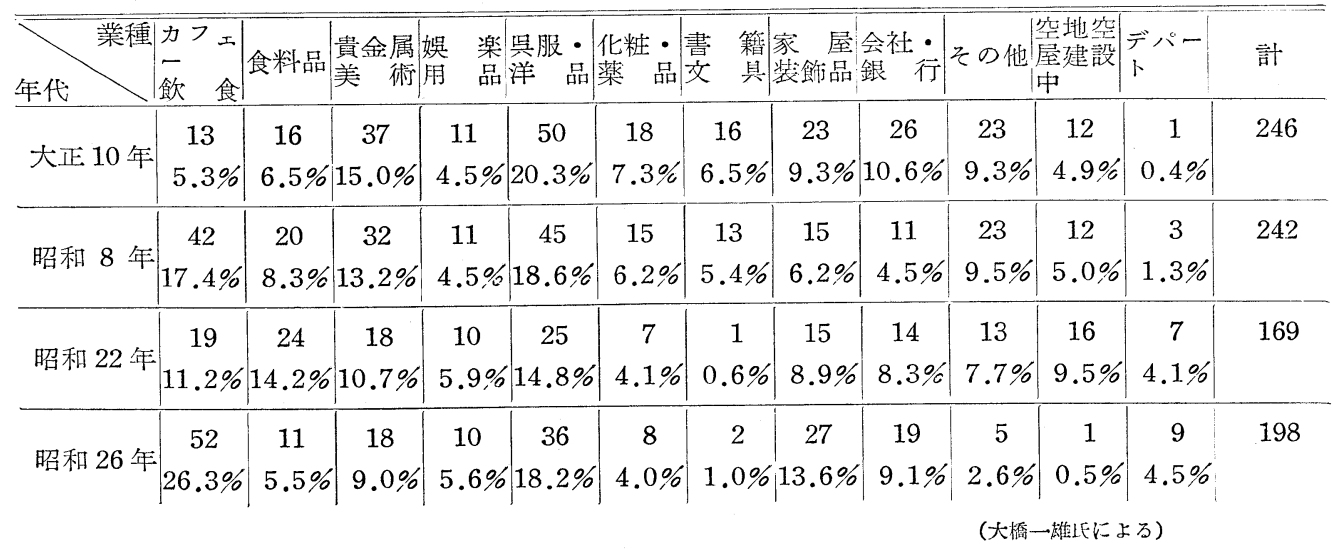


といらたことにふれてみよう。

まず，東京の中心榇店街である銀座通りについて，大正 10 年から炤和 26 年までの間の変化について， 4 期間にわたつて第 9 表に揭示した。

観楽约な㥄格をもつカフェー・飲食店は, 大正 10 年から炤和 8 年へと漸増し, 戦後急激に減少し,さら 飞激堌の傾向にある。

これと反対の傾问を示しているのが食料品店であり，大正 10 年から戦後に至るまで漸増しつつあつた が，その後，急激に減少をたどつている。この現象は戦後の生活程度の笨乏さを物語るものであろう。

貴金属，美術，娛楽胕品などが，がいして減少しつつあるということは，何によるものであろうか。伦

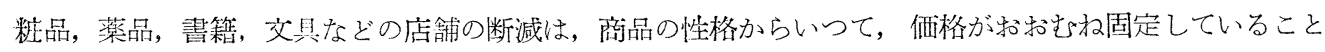
北よるもの之考劣られ，地洒の高騰を呼ぶかかる通りでは，当然の成行きであろう。

與服, 洋品などの小范滴や, 会社銀行などの増减に関しては, 著しい变化は認められない。戦後におけ るデパートの出現は，注目豙べきものであるが，これと共に通りに占める店舗数の 3 割前後の滅少は，大 企業の有利さを物語るものであり，見逃すことの出来ない事実である。

その他の都市については, 第 10 表に示す如くに, 大阪の盛り場・心斎橋筋の店舗構成の変質は, 吳服類 を販売する店赫が滅少し，それに代つて，洋服，洋品店などが堌加していることであり，これは時代の流 れに沿つたというべきであろう。

高級品を取扱う貴金属，時計，眼鏡などに関しては，ほとんど変化はみとめられない。

飲食，喫茶店などは，東京銀座の激增に対して，著しい減少を示していることは，もつとも注目すべき

第 10 表中心商店街の店舖構成の变質

\begin{tabular}{|c|c|c|c|c|c|c|c|c|c|c|c|c|c|c|c|c|c|c|c|c|}
\hline 都市の心中商店街 & \begin{tabular}{l|l} 
洋 & 洋 \\
服 \\
服 \\
地 \\
雑
\end{tabular} & 服 & 物 & 靴 & 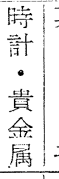 & 菓 & \begin{tabular}{l|} 
䣄 \\
食 \\
喫 \\
茶
\end{tabular} & \begin{tabular}{l|} 
食 \\
料 \\
品
\end{tabular} & \begin{tabular}{l|} 
書 \\
籍 \\
交 \\
具
\end{tabular} & $\left|\begin{array}{c}\text { 薬 } \\
\text { 化 } \\
\text { 料 }\end{array}\right|$ & \begin{tabular}{|} 
鞄 \\
袋 \\
\\
\end{tabular} & $\mid$\begin{tabular}{|} 
洋 \\
夾 \\
毛 \\
系
\end{tabular} & $\mid$ & & $\begin{array}{l}\text { 工 } \\
\text { 芸 } \\
\text { 美 } \\
\text { 術 }\end{array}$ & $\mid \begin{array}{c}\text { 電 } \\
\text { 気 } \\
\text { 器 } \\
\text { 具 }\end{array}$ & 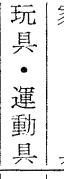 & 具 & \begin{tabular}{l|} 
そ \\
口 \\
他
\end{tabular} & 䛠 \\
\hline 神 戸元町 $\left\{\begin{array}{l}(10.12 .10) \\
(30.8 .20)\end{array}\right.$ & \begin{tabular}{r|r}
18 & 9 \\
19 & 17
\end{tabular} & $\begin{array}{l}16 \\
15\end{array}$ & $\begin{array}{l}8 \\
1\end{array}$ & $\begin{array}{l}12 \\
11\end{array}$ & $\begin{array}{l}21 \\
20\end{array}$ & $\begin{array}{l}15 \\
14\end{array}$ & $\begin{array}{l}24 \\
12\end{array}$ & $\begin{array}{l}19 \\
12\end{array}$ & $\begin{array}{l}12 \\
10\end{array}$ & $\begin{array}{l}4 \\
5\end{array} \mid$ & $\begin{array}{r}7 \\
11\end{array}$ & 14 & 12 & $\begin{array}{l}12 \\
13\end{array}$ & $\begin{array}{r}11 \\
9\end{array}$ & $\begin{array}{l}4 \\
9\end{array} \mid$ & $\begin{array}{r}10 \\
6\end{array}$ & $\begin{array}{r}10 \\
5\end{array}$ & $\begin{array}{r}20 \\
9\end{array}$ & $\begin{array}{l}252 \\
230\end{array}$ \\
\hline 横浜伊勢佳 $\left\{\begin{array}{l}(10.12 .10) \\
(29.8 .\end{array}\right.$ & $\begin{array}{rr}13 & 10 \\
17 & 7\end{array}$ & & $\begin{array}{l}5 \\
0\end{array}$ & $\begin{array}{l}4 \\
5\end{array}$ & $\begin{array}{l}7 \\
6\end{array}$ & $\begin{array}{l}8 \\
3\end{array}$ & $\begin{array}{l}8 \\
4\end{array}$ & 7 & $\begin{array}{l}2 \\
0\end{array}$ & $\begin{array}{l}4 \\
2\end{array}$ & $\begin{array}{l}4 \\
2\end{array}$ & $\begin{array}{l}4 \\
1\end{array}$ & $\begin{array}{l}3 \\
4\end{array}$ & $\begin{array}{r}4 \\
4\end{array}$ & $\begin{array}{l}1 \\
5\end{array}$ & $\begin{array}{l}0 \\
0\end{array}$ & $\begin{array}{l}1 \\
2\end{array}$ & $\begin{array}{l}2 \\
0\end{array}$ & $\begin{array}{l}15 \\
19\end{array}$ & $\begin{array}{r}104 \\
85\end{array}$ \\
\hline 京都四条 $\left\{\begin{array}{l}(10.12 .10) \\
(25.11 .)\end{array}\right.$ & \begin{tabular}{r|r}
11 & 9 \\
18 & 24
\end{tabular} & $\mid \begin{array}{l}18 \\
11\end{array}$ & $\begin{array}{l}5 \\
4\end{array}$ & $\begin{array}{l}4 \\
5\end{array}$ & $\begin{array}{r}15 \\
8\end{array}$ & $\begin{array}{l}15 \\
14\end{array}$ & $\begin{array}{l}15 \\
21\end{array}$ & $\begin{array}{l}4 \\
6\end{array}$ & $\begin{array}{l}4 \\
3\end{array}$ & $\begin{array}{l}7 \\
7\end{array}$ & $\begin{array}{l}10 \\
*\end{array}$ & 4 & $\begin{array}{l}8 \\
3\end{array}$ & \begin{tabular}{r|r}
17 \\
9
\end{tabular} & $\begin{array}{c}8 \\
*\end{array}$ & & $\begin{array}{l}6 \\
2\end{array}$ & $\begin{array}{l}5 \\
3\end{array}$ & $\begin{array}{l}7 \\
4\end{array}$ & $\begin{array}{l}177 \\
149\end{array}$ \\
\hline 大阪心斎橋 $\left\{\begin{array}{l}(10.12 .10) \\
(29.8 .)\end{array}\right.$ & $\begin{array}{ll}28 & 17 \\
20 & 13\end{array}$ & $\begin{array}{r}22 \\
9\end{array}$ & $\begin{array}{l}5 \\
2\end{array}$ & $\begin{array}{l}6 \\
5\end{array}$ & $\begin{array}{l}25 \\
14\end{array}$ & $\begin{array}{r}10 \\
8\end{array}$ & $\begin{array}{r}25 \\
8\end{array}$ & $\begin{array}{l}8 \\
8\end{array}$ & $\begin{array}{l}7 \\
5\end{array}$ & $\begin{array}{l}6 \\
2\end{array}$ & $\begin{array}{r}16 \\
8\end{array}$ & $\mid \begin{array}{r}4 \\
10\end{array}$ & $\begin{array}{r}12 \\
4\end{array}$ & $\begin{array}{r}7 \\
2\end{array}$ & $\begin{array}{l}1 \\
3\end{array}$ & $\begin{array}{l}2 \\
1\end{array}$ & $\begin{array}{l}6 \\
1\end{array}$ & & $\begin{array}{l}31 \\
32\end{array}$ & $\begin{array}{l}240 \\
155\end{array}$ \\
\hline 名 克 屋 $\left\{\begin{array}{l}(10.12 .10) \\
(32.3 .)\end{array}\right.$ & \begin{tabular}{l|l}
2 & 6 \\
1 & 4
\end{tabular} & $\begin{array}{l}4 \\
1\end{array}$ & $\begin{array}{l}2 \\
1\end{array}$ & $\begin{array}{l}2 \\
3\end{array}$ & $\begin{array}{r}5 \\
3\end{array}$ & $\begin{array}{r}11 \\
8\end{array}$ & $\begin{array}{r}10 \\
7\end{array}$ & $\begin{array}{l}6 \\
0\end{array}$ & $\begin{array}{l}4 \\
1\end{array}$ & $\begin{array}{l}4 \\
3\end{array}$ & $\begin{array}{l}2 \\
3\end{array}$ & $\begin{array}{l}0 \\
0\end{array}$ & $\begin{array}{l}8 \\
3\end{array}$ & $\begin{array}{l}3 \\
2\end{array}$ & $\begin{array}{l}2 \\
1\end{array}$ & $\begin{array}{l}0 \\
2\end{array}$ & $\begin{array}{l}0 \\
0\end{array}$ & $\begin{array}{l}0 \\
0\end{array}$ & $\begin{array}{l}27 \\
17\end{array} \mid$ & $\begin{array}{l}98 \\
60\end{array}$ \\
\hline 仙 僠一台 $\left\{\begin{array}{l}(10.12 .10) \\
(31.10 .20)\end{array}\right\}$ & $\begin{array}{r}6 \\
11\end{array}$ & $\begin{array}{l}6 \\
2\end{array}$ & $\begin{array}{l}5 \\
5\end{array}$ & $\begin{array}{l}5 \\
6\end{array}$ & \begin{tabular}{l|l}
7 \\
7
\end{tabular} & \begin{tabular}{l|l}
13 & 2 \\
11 &
\end{tabular} & $\begin{array}{l}20 \\
18\end{array}$ & $\begin{array}{l}22 \\
11\end{array}$ & $\begin{array}{l}8 \\
8\end{array}$ & $\begin{array}{l}7 \\
5\end{array}$ & $\begin{array}{l}5 \\
3\end{array}$ & $\begin{array}{l}7 \\
2\end{array}$ & $\begin{array}{l}7 \\
8\end{array}$ & $\begin{array}{l}12 \\
12\end{array}$ & $\begin{array}{l}0 \\
2\end{array}$ & \begin{tabular}{l|}
2 \\
7
\end{tabular} & $\begin{array}{l}7 \\
6\end{array}$ & $\begin{array}{l}6 \\
1\end{array}$ & $\begin{array}{l}8 \\
8\end{array}$ & $\begin{array}{l}153 \\
133\end{array}$ \\
\hline 新潟古町 $\left\{\begin{array}{l}(10.12 .10) \\
(31.10 .23)\end{array}\right.$ & $\begin{array}{l}4 \\
8\end{array}$ & $\begin{array}{l}3 \\
2\end{array}$ & $\begin{array}{l}3 \\
2\end{array}$ & $\begin{array}{l}3 \\
1\end{array}$ & $\begin{array}{l}6 \\
0\end{array}$ & \begin{tabular}{l|l}
5 & 1 \\
5 &
\end{tabular} & $\begin{array}{r}10 \\
7\end{array}$ & $\begin{array}{l}4 \\
3\end{array}$ & $\begin{array}{r}6 \\
4\end{array}$ & $\begin{array}{l}3 \\
3\end{array}$ & $\begin{array}{l}1 \\
2\end{array}$ & $\begin{array}{l}4 \\
1\end{array}$ & $\begin{array}{l}6 \\
2\end{array}$ & $\begin{array}{l}8 \\
4\end{array}$ & $\begin{array}{l}1 \\
1\end{array}$ & $\begin{array}{l}4 \\
2\end{array}$ & $\begin{array}{l}2 \\
1\end{array}$ & $\begin{array}{l}2 \\
6\end{array}$ & $\begin{array}{l}10 \\
18\end{array}$ & $\begin{array}{l}85 \\
72\end{array}$ \\
\hline
\end{tabular}


事実であろう。すなわち，東京銀座は，次第に盛り場的嚆店街となりつつあるのに対して，大阪心斎橋筋 は; 次第に純粋の買物商店街に変りつつあるということであり，神戸の元町についても同じ傾向を示して いる。また，構成店舗の数の著しい減少が認められ，同じ現象は，名古屋の盛り場広小路についてもい兄 るであろら。

洋服, 吳服類, 書籍, 文具の著しい減少を除いて, 大きな变化はみとめられない。

神戸の元町は, 第 10 表から知れるように，もつとも変化の少い通りといえよう。ただ洋品雑貨㯁が減少 て，これに代つて，洋服商が増加した点のみが指摘される。

貴金属，㫢計份などの占める割合が多いことは，東京，大阪の中心墑店街についても指摘することが出 来る。

横浜の中心滴店街伊勢佐木 $4 \cdot 5$ 丁目筋については，只服商の激減とこれに対する洋服商の激增が 目立 つ，また，飲食店拈よび洒格の固定した書籍，交具，薬品，化籸などは幾分減少の傾问にあるほか，大き な変化はみとめられない。

ついで，人口 37.8 万を算光る大都市仙台市に特ける中心商店街東一番町の店舖構成で注目すべき点は，

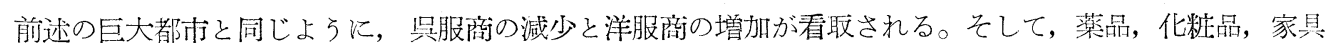
の諸店舗の減少が指摘されるが，これらについての解粧としては前に述べてきた。

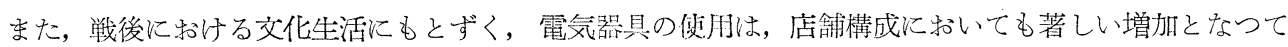
現われる。同じ中心垶店街に和ける店赤の減少は，2 3 割を示す。人口 27.8 万を算光る新潟市の中心商 店街古町でも，まず飲食店舗の著しい増加が指摘され，それと共に，洋服商の増加がみられる。

東京, 大阪などの巨大都市の盛場では, 書籍, 交具, 化粧, 薬品などの諸店舗が滅少しているにもかか わらず，新潟市の盛場では堌加の傾向にある。これとほぼ同じことは，仙台市の中心商店街についてもい 光る。

\section{V. 要 約}

以上述べてきたことは，つぎの如く要約されるであろう。

（1）都市内部に批いて，周辺部から中間，都心地域光と攵ぶにつれて，そこに拈ける中心商店街は，衣 料, 身迴品拉上び文化品を主とする筫迴り品で構成される割命が著しくなり，これと同じ傾向は，小都市 から大都市へ進む，都市規模の変化に括いて認められる。

（2）中心商店街に扔将る小売店舗の壳場面積とその間口，奥行との関係を久ると，巨大大都市の中心商

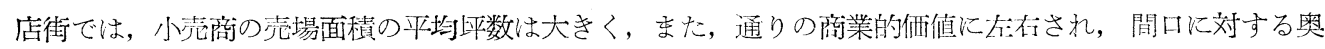

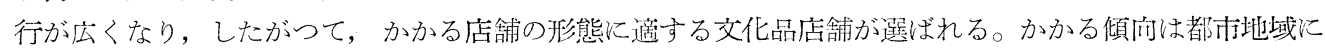
打いてもみとめられる。

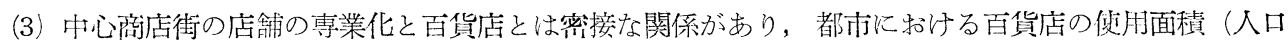
1 人当りの坪数）の增大と共に，人口 1 人当りの范上高は高くなるとい5傾问が拈括むね指摘される。

な拉，都市で消費される小売金額からみた後背地人口率の堌大と，前述の百貨店の人口 1 人当りの売上

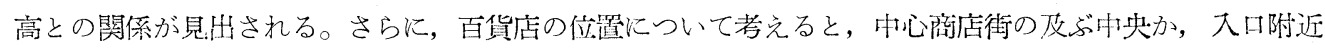
にあるものが，概して売場面積に対する売上高が一層高い傾向にある。

（4）中心商店街の店舗構成に関する変質作用について，一般にいえることは昭和 10 年に比較して，今日 では洋服墑が增加し，これに対して，只服商が減少を示していることである。

さらに，都市替模によつて検討すると，巨大都市では，洏格の比較的一定した薬品，化粧，書籍，交具

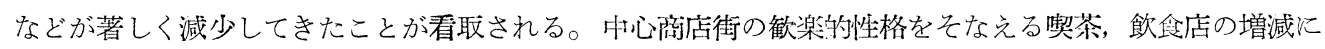
ついてみると, 東京の盛場銀座では, 戦後急激な増加を示しているが, これに対して, 大服の盛場心斎橋 筋, 横浜の伊勢佐木, 名占屋の広小路などは著しい減少となつている。また，中心商店街飞占事業所 
の数は, 3 分の 2 に減少していることが看取される。

[註]

1）アフリカ怙よび，小アジア地域では, 現在でも, バザールによつてのみ経济的機能が果をされている ところがある。

2) 拙稿 中心商店街々副次的商店街. 都市学会年報 1 号飞揭載子定。

3）伊豆下田は，旧町の 9 千人と，合併による諸村落をあわせて，2万人を算える。

4）盛岡市綜合調查の結果報告とよる。

5）広島市の 28 年废の商業統計による。

6) 東京銀座，大阪心斎橋を除を実地調查によるもの（店舖の売場面積の測定不可能なるものを除いた 残りの店舖の平均值を求めた。したがつて, 数字の值は, 概数を示すむのである。)

7）東京都商工指導所商店課による東京都に扣ける商店街の現状についての実態調查の敨告による。

8）小古間隆蔵 $(1955)$ ：デパートのある都市，市政， 4 巻 4 号， $72 \sim 74$. 参照。

9) 拙稿 都市の商業機能, 都市問題研究, 8 巻 3 号. 参照。

10）人口 30 万以上の都市の百貨店と中心商店街との位置の関係のみをみたのは, 30 万以上の都市の百貨 店の数の多数と, 市域の分化による副都心の発生なぞの影響にもとずいて，ててで把えようとする 現象がはつきりつかめがたいととによるものである。 